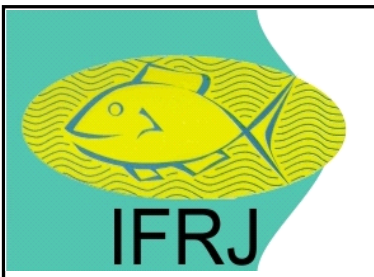

Available online at: http://ejournal-balitbang.kkp.go.id/index.php/ifrj

$$
\text { e-mail:ifrj.puslitbangkan@gmail.com }
$$

INDONESIANFISHERIES RESEARCHJOURNAL

Volume 24 Nomor 2 December 2018

p-ISSN: 0853-8980, e-ISSN: 2502-6569

Accreditation Number RISTEKDIKTI: 21/E/KPT/2018

http://dx.doi.org/10.15578/ifrj.23.2.2017.91-98

\title{
SOME POPULATION PARAMETERS AND EXPLOITATION STATUS OF FOURFINGER THREADFIN (Eleutheronema tetradactylum Shaw, 1804) IN TARAKAN WATERS, NORTH KALIMANTAN
}

\author{
Tirtadanu $^{\star 1}$ and Umi Chodrijah ${ }^{1}$ \\ ${ }^{1}$ Marine Fisheries Research Institute, Jl. Raya Bogor KM. 47 Nanggewer Mekar, Cibinong, Bogor, West Java, Indonesia \\ Received; December 29-2017 Received in revised from Augst 03-2017; Accepted Augst 07-2018
}

\begin{abstract}
Information on exploitation status of fourfinger threadfin (Eleutheronema tetradactylum Shaw, 1804) is important for sustainable gillnet fisheries management in Tarakan, North Kalimantan waters. In an attempt of providing scientific data and information on the exploitation status of this species, a research work was conducted from January to November 2016 in Selumit landing place. Fish sampling was done by trained enumerator on bottom gillnet catches landed through semi-regular observation. A total of 1964 specimens were collected and measured. The results showed that the size ranged between $16-70 \mathrm{cmFL}$ with an average of $37.72 \pm 0.36 \mathrm{cmFL}$. The length at first captured (Lc) of about $38.5 \mathrm{cmFL}$, was smaller than the length at first mature of female (Lm) of $39.6 \mathrm{cmFL}$. The growth pattern was negative allometry. By applying von Bertalanffy growth model, it was found that growth model for this species was $L(t)=75,8\left(1-\mathrm{e}^{0,3(t+0,035)}\right)$. Exploitation rate $(E)$ was 0,47 . It showed that the exploitation status of fourfinger threadfin in Tarakan Waters was still sustainable.
\end{abstract}

Keywords: Exploitation rate; fourfinger threadfin; population parameter; Tarakan Waters

\section{INTRODUCTION}

Tarakan waters, which is geographically located in eastern part of North Kalimantan province, is the fishing area of Fisheries Management Area (FMA) 716. One of the important economic species of demersal fishes belong to polynemids family that was exploited in Tarakan was fourfinger threadfin (Eleutheronema tetradactylum Shaw, 1804) or locally named as Senangin. About $84 \%$ of fourfinger threadfin caught in Tarakan waters was exported and about $16 \%$ was consumed by local resident in Tarakan so it provided high potential fish nutrition and contribute economical impact for local community.

Fourfinger threadfin ( $E$. tetradactylum) in Tarakan was mainly caught by bottom gillnet. The estimate number of gillnet boats operated in Tarakan were 1.019 vessels and the production of fourfinger threadfin in 2014 was 483 tonnes or $0.8 \%$ from total production of fourfinger threadfin in Indonesia (DGCF, 2015). Exploitation status of demersal fisheries in FMA 716 was still at moderate level (Ministerial decree No. 50/ KEPMEN-KP/2017). Exploitation status by species, especially for fourfinger threadfin, could be as supporting information for local management plan of demersal fisheries in Tarakan. The exploitation status of fourfinger threadfin could be predicted by studying about its population parameters.

Information on population parameters of fourfinger threadfin ( $E$. tetradactylum) in Indonesia was still limited. The previous information available particularly related to feeding habit and its exploitation status in East and South Sumatra (Rengi et al., 2015., Ridho et al., 2010). Population parameters of fourfinger threadfin in Tarakan waters hadn't been reported yet. Therefore, this study was needed to provide biological indicator as part of exploitation status for supporting sustainable fisheries management in this particular area.

\section{MATERIALS AND METHODS}

Samples of fourfinger threadfin were collected from small scale bottom gillnet catches landed in Selumit, one of the main fish landing places in Tarakan, North Kalimantan (Figure 1), during January-November 2016. All samples were measured fork length ( $F L$, to nearest centimeter) and weight (to nearest gram), and were identified for sex and maturity level. 


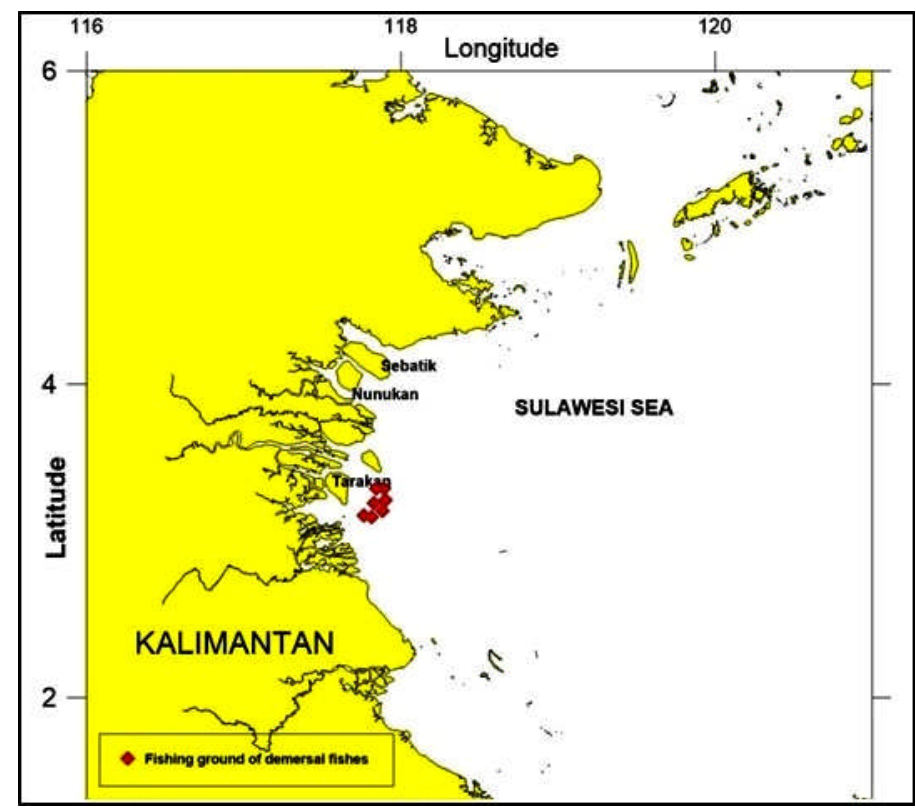

Figure 1. Fishing ground of small scale bottom gillnet fisheries in Tarakan Waters.

Monthly length frequency distribution was plotted and analyzed with the interval size of $3 \mathrm{~cm}$ and treated as a basic data for further analysis. The length-weight relationship was performed by (King, 1995):

$\mathrm{W}=\mathrm{a} \mathrm{L}^{\mathrm{b}}$

Where, W=weight $(\mathrm{g})$; L=Fork Length $(\mathrm{cm})$ and $a, b=$ regression constant

Estimation of length at first captured (Lc) was determined based on logistic curve by (Sparre \& Venema, 1992):

$$
S_{L}=\frac{1}{1+\exp (a-b * L)}
$$

Where $a=$ the intercept of regression, $b=$ the slope of regression, $S_{L}=$ logistic curve and $L C$ is determined by $\mathrm{a} / \mathrm{b}$.

Length at first maturityd $(\mathrm{Lm})$ was analyzed based on logistic curve (King, 1995):

$$
P_{L m}=\frac{1}{1+\exp (a L+b)}
$$

Where $a=$ the intercept of regression, $b=$ the slope of regression, $P_{L m}=$ logistic curve of proportion mature by length, Lm was determined by a/b.

Growth parameters, including asymptotic length $\left(L_{\infty}\right)$ and growth rate $(K)$, were estimated by Electronic Length Frequency Analysis/ELEFAN I in
FISAT II packages (Gayanilo et al., 2005). Theoretical age when the fish has zero length $\left(\mathrm{t}_{0}\right)$ was calculated based on the equation of Pauly (1983):

$$
\begin{aligned}
& \log \left(-t_{0}\right)=-0,3922-0,2752 \log \left(L_{\infty}\right)-1,038 \log \\
& (\mathrm{K})
\end{aligned}
$$

The von Bertalanffy growth model was used to fit a curve of mean length and estimated age by following equation of Sparre \& Venema, (1992):

$L_{t}=L \infty\left[1-e^{-k\left(t-t_{0}\right)}\right]$

Where, $L t$ is the fork length at age $t,]_{\infty}$ is asymptotic fork length $(\mathrm{cm}), \mathrm{K}$ is the growth rate of fish and $t_{0}$ is the point at time when the fish has zero length.

Total mortality was estimated by applying length converted catch curve in FISAT II packages (Pauly, 1983; Gayanilo et al., 2005). Natural mortality (M) was estimated by using Pauly et al. (1984) formula with $29^{\circ} \mathrm{C}$ sea surface temperature:

$$
\begin{aligned}
\log (M)= & -0,0066-0,279 \log \left(L_{\infty}\right)+0,6543 \log (K) \\
& +0,4634 \log (T) \ldots \ldots \ldots \ldots \ldots \ldots \ldots \ldots \ldots \ldots \ldots \ldots \ldots \ldots \ldots \ldots
\end{aligned}
$$

Fishing mortality and exploitation rate was estimated by (Sparre \& Venema, 1992):

$\mathrm{F}=\mathrm{Z}-\mathrm{M}$ and $E=\frac{F}{Z}$ 


\section{RESULTS AND DISCUSSION Results}

\section{General Description on Data Collection}

Numbers of specimens were measured on monthly basis, the biometric description of fourfinger threadfin showed that the length of fourfinger threadfin ranged between 13-68 cmFL. The weight ranged between 90 - $4640 \mathrm{~g}$ (Table 1).

The data showed that the average of length for each month was between $32.1-43.4 \mathrm{~cm}$ FL and the average of weight for each month was between 585.5 $-1586.9 \mathrm{~g}$. The maximum average of length and weight for fourfinger threadfin was obtained in January.

\section{Length Frequency}

The total samples of gillnet fishery from January until November 2016 were 1,964 fish (Figure 2). The fork length $(\mathrm{FL})$ of fourfinger threadfin ( $E$. tetradactylum Shaw, 1804) ranged between 16-70 cm FL with an average of $37.72 \pm 0.36 \mathrm{~cm} \mathrm{FL}$ and the mode was 40 cm FL (Figure 2).

Table 1. The average of length and weight per month for fourfinger threadfin (E. tetradactylum) in Tarakan waters, 2016.

\begin{tabular}{ccccccccccc}
\hline \multirow{2}{*}{ No } & Period of & \multirow{2}{*}{$\mathbf{n}$} & \multicolumn{4}{c}{ Length (cmFL) } & \multicolumn{4}{c}{ Weight (g) } \\
\cline { 4 - 11 } & sampling & & Max & Min & $\mathbf{~}$ & std & Max & Min & X & std \\
\hline 1 & Jan & 104 & 68 & 21 & 42.3 & 10.9 & 4640 & 104 & 1586.9 & 1260.8 \\
2 & Feb & 120 & 56 & 20 & 35.5 & 8.3 & 2680 & 137 & 804.7 & 539.4 \\
3 & Mar & 130 & 58 & 24 & 35.7 & 7.2 & 2721 & 210 & 792.1 & 494.9 \\
4 & Apr & 200 & 60 & 22 & 43.1 & 8.6 & 3609 & 161 & 1479.2 & 736.8 \\
5 & May & 200 & 65 & 20 & 43.4 & 10.0 & 4625 & 178 & 1407.3 & 1033.3 \\
6 & Jun & 269 & 60 & 13 & 32.1 & 7.4 & 3148 & 97 & 601.8 & 416.1 \\
7 & Jul & 200 & 43 & 23 & 32.9 & 5.0 & 1320 & 138 & 585.5 & 264.1 \\
8 & Aug & 227 & 62 & 23 & 37.7 & 6.1 & 3450 & 212 & 828.9 & 492.1 \\
9 & Sep & 200 & 48 & 25 & 37.7 & 4.5 & 1368 & 234 & 789.2 & 283.2 \\
10 & Oct & 262 & 57 & 27 & 38.9 & 5.6 & 3668 & 281 & 901.1 & 469.4 \\
11 & Nov & 52 & 59 & 19 & 38.6 & 9.2 & 2850 & 90 & 958.1 & 638.7 \\
\hline
\end{tabular}

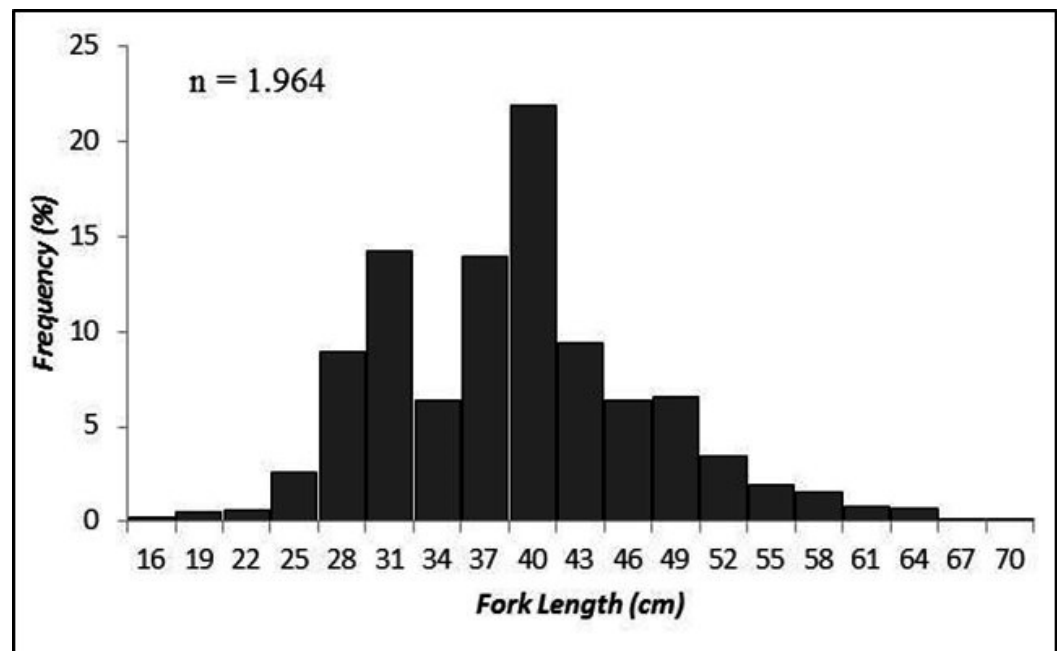

Figure 2. Annual length frequency distribution of fourfinger threadfin (E. tetradactylum) in Tarakan waters, 2016.

\section{Length-Weight Relationship}

Based on the monthly length-weight relationship, the result showed that the $95 \%$ confidence value of $b$ was 2.42 - 2.7 in March and 2.68-2.98 in June or the value of $b$ was significantly different from 3 that indicated the negative allometry $(p<0.05)$ in March and June. This condition showed that the growth in length in March and June was faster than the growth in weight. The length-weight relationship in the other months showed that the value of $b$ was not significantly different from $3(p>0.05)$ that means the growth in length was equal as the growth in weight (Table 2). 
Table 2. Monthly length-weight relationship of fourfinger threadfin (Eleutheronema tetradactylum) in Tarakan waters, 2016.

\begin{tabular}{|c|c|c|c|c|c|c|}
\hline No & sampling month & $\mathbf{n}$ & $a$ & $b$ & $\mathbf{R}^{2}$ & $\begin{array}{c}95 \% \\
\begin{array}{c}\text { Confidence interval } \\
\text { of } b\end{array} \\
\end{array}$ \\
\hline 1 & January & 48 & 0.0067 & 3.1741 & 0.87 & $2.81-3.54$ \\
\hline 2 & February & 120 & 0.0201 & 2.9258 & 0.93 & $2.78-3.07$ \\
\hline 3 & March & 130 & 0.0765 & 2.5582 & 0.91 & $2.42-2.70$ \\
\hline 4 & April & 120 & 0.0136 & 3.0308 & 0.97 & $2.94-3.12$ \\
\hline 5 & May & 120 & 0.0163 & 2.9807 & 0.97 & $2.88-3.08$ \\
\hline 6 & June & 189 & 0.027 & 2.8373 & 0.89 & $2.68-2.98$ \\
\hline 7 & July & 120 & 0.0276 & 2.8387 & 0.85 & $2.62-3.05$ \\
\hline 8 & August & 147 & 0.0147 & 2.9998 & 0.96 & $2.90-3.10$ \\
\hline 9 & September & 100 & 0.0176 & 2.9527 & 0.89 & $2.74-3.16$ \\
\hline 10 & October & 182 & 0.0107 & 3.0835 & 0.94 & $2.97-3.19$ \\
\hline 11 & November & 52 & 0.0192 & 2.9205 & 0.97 & $2.85-3.50$ \\
\hline
\end{tabular}

The plot of the growth coefficient $(b)$ monthly based length-weight relationship (Figure 3 ) showed that the value tends to be high in January then it was low in March, while ones in other months seem to fluctuate. The fluctuation of $b$ in some months could be caused by spawning season and the growth (Uchiyama \& Boggs, 2006).
Combining all monthly length and weight data, the relationship between length and weight of fourfinger threadfin in Tarakan waters was determined as $\mathrm{W}=0.0212^{*} \mathrm{~L}^{2.9054}$ (Figure 4). The 95\%confidence interval of $b$ was 2.86-2.95 so the value of $b$ was significantly different from3 $(p<0.05)$ or the negative allometry that means the growth in length was faster than the growth in weight.

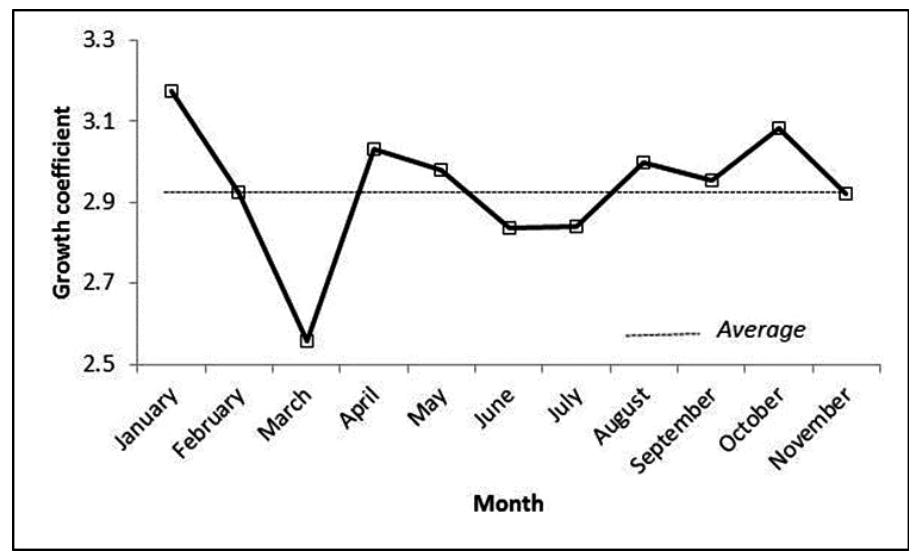

Figure 3. Monthly variability on growth coefficient of fourfinger threadfin (E. tetradactylum) in Tarakan waters, 2016.

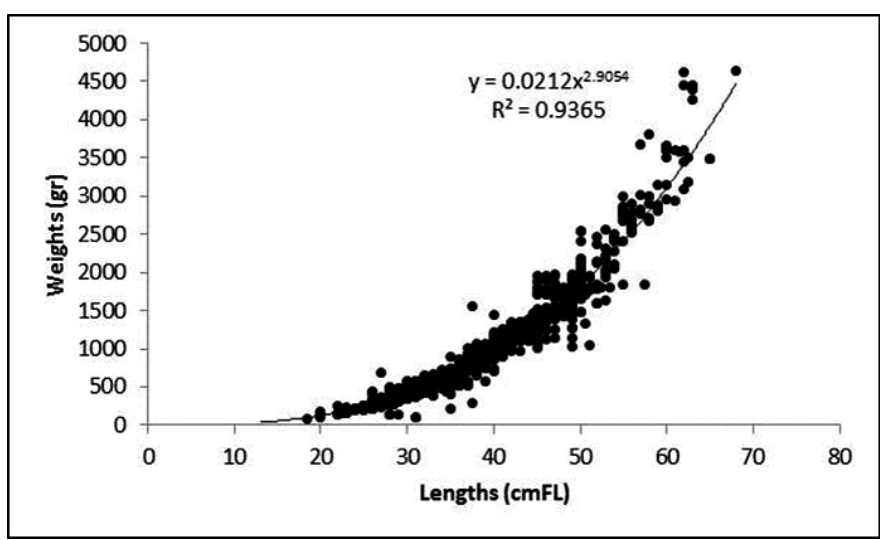

Figure 4. Length-Weight relationship off ourfinger threadfin (E. tetradactylum) in Tarakan waters, 2016. 


\section{Length at First Captured (LC) and Length at First Maturity (Lm)}

The monthly proportion of mature (stage III and stage IV) to immature (stage I and stage II) gonad showed that the fourfinger threadfin (E. tetradactylum) spawned along the year and the peak was estimated in January and June. The proportion of $>50 \%$ mature fish occurred during January to June with range of proportion was 60 to $88 \%$ (Figure 5). The same period of spawning season in January and June occurred in Chilka lake and the other period of spawning season in March until September occurred in Malacca strait (Patnaik, 1970; Zamidi et al., 2012).

The estimation of length at first captured (Lc) of fourfinger threadfin (E. tetradactylum) is $38.5 \mathrm{~cm}$ and length at first matured $(\mathrm{Lm})$ is $39.6 \mathrm{~cm}$ (Figure 6). The short gap between $\mathrm{Lm}$ and $\mathrm{Lc}$ indicated that almost $50 \%$ of fish caught by gillnet were already spawned.

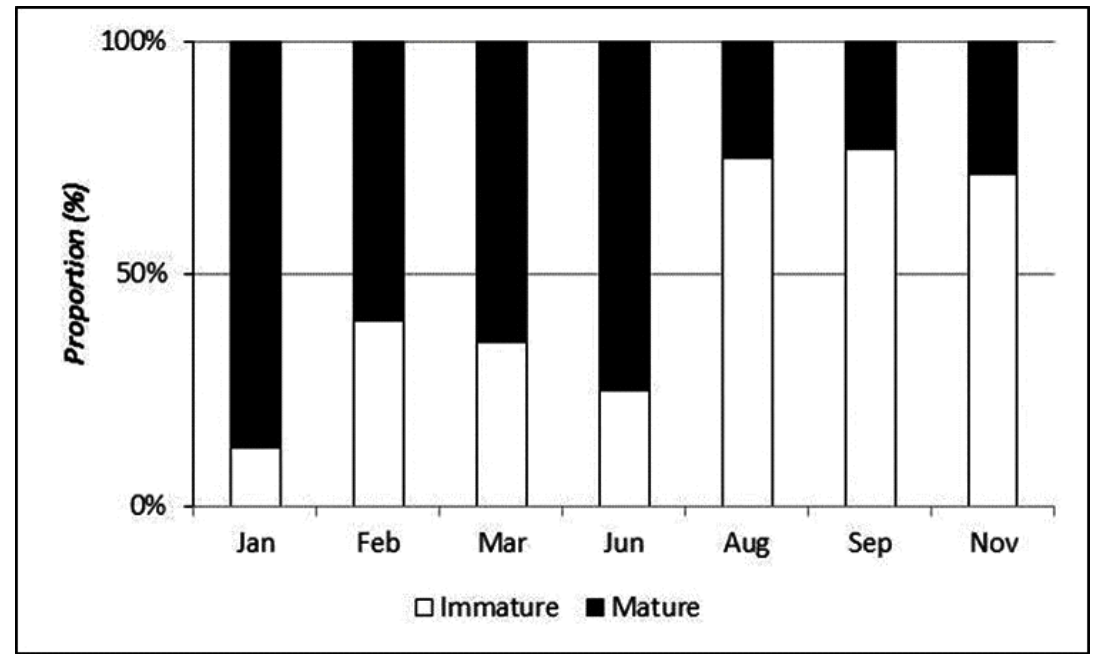

Figure 5. Proportion of gonad maturity for female fourfinger threadfin (E. tetradactylum) in Tarakan waters, 2016.

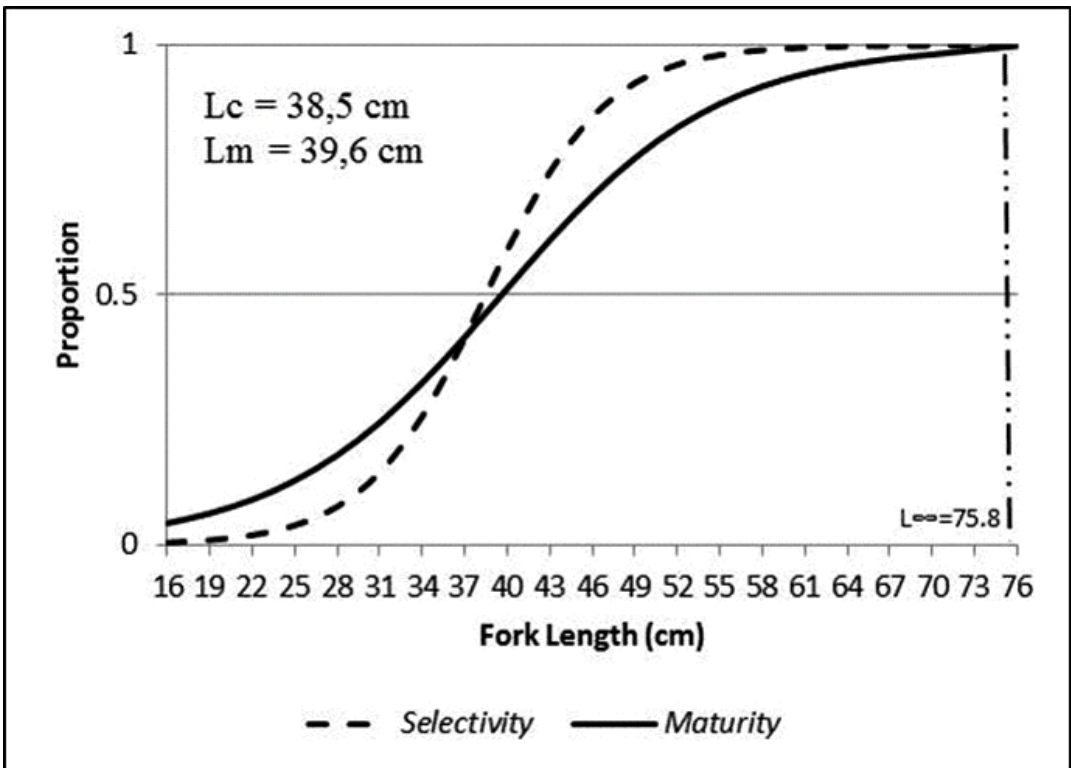

Figure 6. Length at first captured $(\mathrm{Lc})$ and length at first maturity $(\mathrm{Lm})$ of fourfinger threadfin ( $E$. tetradactylum)

\section{Growth} in Tarakan waters, 2016

The growth parameters including the asymptotic length $\left(\mathrm{L}_{\infty}\right)$ and the growth rate $(\mathrm{K})$ was obtained from the shifting modes for each month frequency distribution determined by ELEFAN I. The results showed that there are more than one mode for each month that means more than one cohort of fish were catched by gillnet in Tarakan. The estimated asymptotic length $\left(L_{\infty}\right)$ was $75.8 \mathrm{~cm}$ with the growth rate of 0.3 year $^{-1}$ (Figure 7). Theoretical age when the fish at zero length $\left(\mathrm{t}_{0}\right)$ was 0.035 year so the Von 
Bertalanffy growth model was determined as $L(t)=$ $75.8\left(1-e^{-0.3(t+0.035)}\right)$.

The maximum length was estimated to be reached at relative age about 10 years, while the length at first mature $(\mathrm{Lm}=39.6 \mathrm{~cm})$ correspond to the age of $28-30$ months (2.5 years) old (Figure 8 ). The result of analysis suggested that the fish is long-lived species.

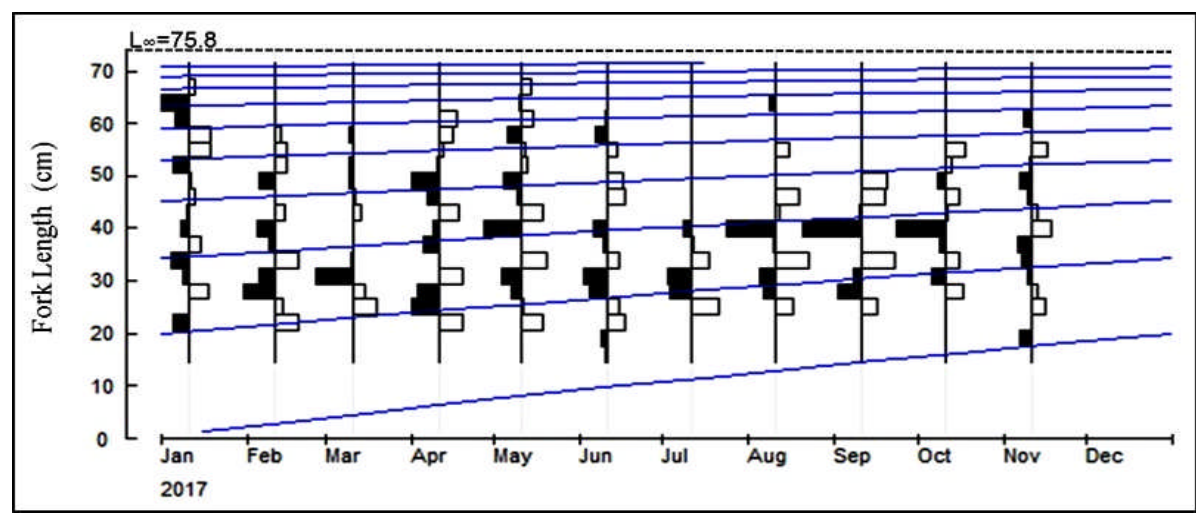

Figure 7. Von Bertalanffy growth curve of fourfinger threadfin (E. tetradactylum) in Tarakan waters, 2016.

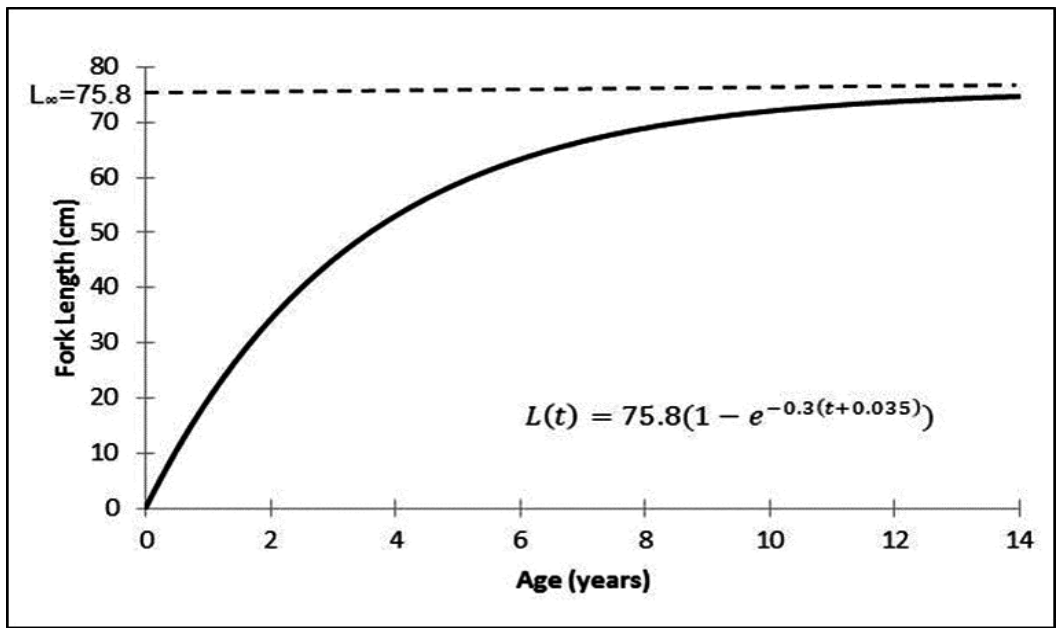

Figure 8. Age and growth of fourfinger threadfin (E. tetradactylum) in Tarakan waters, 2016.

\section{Mortality and Exploitation Rate}

The instantaneous total mortality $(Z)$ and natural mortality $(M)$ were 1.2 year $^{-1}$ and 0.64 year $^{-1}$, respectively. The fishing mortality $(F)$ was estimated at 0.56 year $^{-1}$ and the exploitation rate $(E)$ was 0.47 (Figure 9). The optimum exploitation rate based on Gulland (1983) is 0.5 , so the exploitation rate of fourfinger threadfin (E. tetradactylum) in Tarakan waters was still at sustainable level.

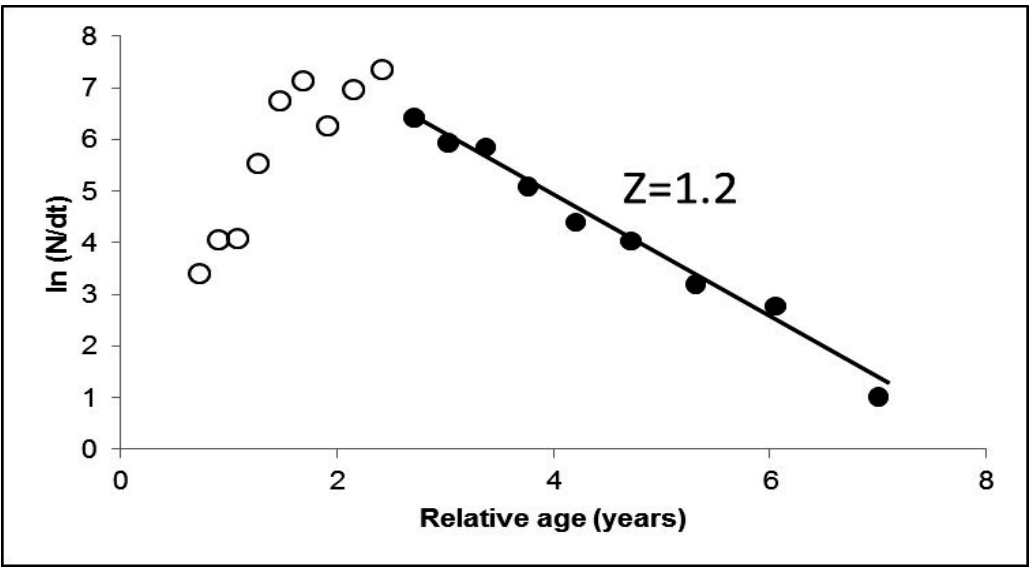

Figure 9. Length-converted catch curve of fourfinger threadfin (E. tetradactylum) in Tarakan waters, 2016. 


\section{Discussion}

One of demersal fishes that economically important in Tarakan is fourfinger threadfin (Eleutheronema tetradactylum Shaw, 1804) It contributes $11.2 \%$ to the total demersal fishery in North Kalimantan Province (DGCF, 2015). The fork length of fourfinger threadfin, which was caught by gillnet in Tarakan waters, was ranged between 16-70 $\mathrm{cm} \mathrm{FL}$ that was larger than size caught in Malacca strait $(38-55.5 \mathrm{~cm})$ by the similar type of fishing gear (Zamidi et al., 2012). The different of fish size was caused by environmental condition and level of exploitation (Campbell et al., 2014). The size was relatively large probably due to different level of exploitation and not overfished yet.

The growth coefficients of fourfinger threadfin were fluctuated between January until November and the highest growth coefficient occurred in January. This was probably related to spawning season that the highest proportion of mature female occurred in that period. Uchiyama and Boggs (2006) noted that this species reaches its highest growth coefficient at the beginning of the spawning season. Combining all monthly length and weight data, the growth pattern was negative allometry. The growth pattern of this species in South Sumatera waters and Chilika, India, was positive allometry, while the growth pattern in Persian Gulf was isometry (Ridho et al., 2010; Karna et al., 2012; Kazemi et al., 2013). The variation of the growth pattern could be caused by season, different ecosystem, and food availability (Ndiaye et al., 2015; Kazemi et al., 2013).

The estimated asymptotic length $\left(L_{\infty}\right)$ of fourfinger threadfin in Tarakan waters (E. tetradactylum) was $75.8 \mathrm{~cm}$ with the growth rate $(K)$ of 0.3 year $^{-1}$. The asymptotic length and the growth rate of the species in the present study were very close to the estimated values found by Pember et al., (2005) that were 76.2 $\mathrm{cm} \mathrm{FL}$ and 0.351 year $^{-1}$. E. tetradactylum was hermaphrodite species that changes sex from male to female at size of $28 \mathrm{~cm} \mathrm{FL}$ (Motomura, 2004). The length at first mature of female $E$. tetradactylum in the present study was $39.6 \mathrm{~cm}$ and reached that size at the age of 2 years. The length at first mature $(\mathrm{Lm})$ of female E. tetradactylum based on Kagwade (1970) ranged between $36-39 \mathrm{~cm}$ and reached that size at the age of 2 years. The maximum age of fourfinger threadfin in Tarakan waters was estimated by more than 10 years so it was presumably as the long-lived species.

The annual fishing mortality $\left(F=0.56\right.$ year $\left.^{-1}\right)$ of fourfinger threadfin in Tarakan waters was smaller than the annual natural mortality $\left(M=0.64\right.$ year $\left.^{-1}\right)$ so the annual exploitation rate $(E)$ of fourfinger threadfin was determined as 0.47 . The exploitation rate of fourfinger threadfin in Tarakan was below the optimum exploitation rate based on Gulland (1983) that is 0.5 . It means that the exploitation status of fourfinger threadfin in Tarakan waters was still sustainable. This study suggested that the fishing of fourfinger threadfin in Tarakan waters with selective gear could be an alternative option for the changing of shrimp trawl to gillnet.

\section{CONCLUSION}

The size of fourfinger threadfin (Eleutheronema tetradactylum Shaw, 1804) ranged between $16-70 \mathrm{~cm}$ FL. The growth pattern was negative allometry. The gillnet that was used to catch this species was relatively selective which has the length at first captured $(\mathrm{LC}=38.5 \mathrm{~cm})$ close to the length at first maturity $(\mathrm{Lm}=39.6 \mathrm{~cm})$. Asymptotic length of the species $\left(L_{\infty}\right)$ was $75.8 \mathrm{~cm}$ and the growth rate $(K)$ was 0.3 year $^{-1}$. The estimation of maximum age was more than 10 years old. The exploitation rate $(E)$ was 0.47 so it showed that the exploitation of $E$. tetradactylum in Tarakan waters was still under sustainable condition.

\section{ACKNOWLEDGEMENTS}

This study was carried out based on data collected during Fish Stock Assessment in house research Program in Fisheries Management Area 716 in 2016, Research Institute for Marine Fisheries (RIMF).

\section{REFERENCES}

Campbell, S. J., Mukminin, A., Kartawijaya, T., Huchery, C., \& Cinner, J. E. (2014). Changes in a coral reef fishery along a gradient of fishing pressure in an Indonesian marine protected area. Aquatic Conservation: Marine and Freshwater Ecosystems, 24(1), 92-103.

Directorate General of Capture Fisheries (DGCF). (2015). Capture fisheries statistics of indonesia by Province, 2014. Directorate General of capture Fisheries. p. 325.

Gayanilo, F. C. Jr., Sparre, P., \& Pauly, D. (2005). FAO-ICLARM stock assessment tools II (FISAT II). Revised version. User's guide. FAO Computerized Information Series (Fisheries) No. 8. Revised Version. FAO Rome.

Gulland, J. A. (1983). Fish stock assessment (p. 233). A Manual of Basic Methods. Chicester: John Wiley and Sons. 
Kagwade, P. V. (1970). The polynemid fishes of India. Bull. Cent. Mar. Fish. Res. Inst, 18, 1-69.

Karna, S.K., Sahoo, D.K., \& Panda, S. (2012). Length-weight relationship (LWR), growth estimation and length at maturity of Eleutheronema tetradactylus in the Chilika Lagoon, India. South Asian Journal of Experimental Biology, 2(3), 97-102.

Kazemi, S. H., Paighambari, S. Y., Daliri, M., \& Naderi, R. A. (2013). Length-weight and lengthlength relationships, condition factors and optimal length of some fish species from the Persian Gulf and Oman Sea. Int. J. Aquat. Biol, 1(4), 167-174.

King, M. (1995). Fishery biology, assessment and management (p. 341). United Kingdom: Fishing New Books.

Motomura, H. (2004). Threadfins of the world (Family Polynemidae). FAO Species Catalogue for fishery Purposes No.3. FAO. Rome. 117 p.

Ndiaye, W., Diouf, K., Samba, O., Ndiaye, P., \& Panfili, J. (2015). The length-weight relationship and condition factor of white grouper (Epinephelus aeneus, Geoffroy Saint Hilaire, 1817) at the southwest coast of Senegal, West Africa. International Journal of Advanced Research, 3(3), 145-153.

Patnaik, S. (1970). A contribution to the fishery and biology of Chilka Sahal Eleutheronema tetradactylum (Shaw). Curr. Sci, 36, 33-61.

Pauly, D. (1983). Some simple methods for the assessment of tropical fish stocks. FAO Fisheries Technical Paper, 254, 52.

Pauly, D. (1984). Length-converted catch curves: a powerful tool for fisheries research in the tropics. Part II Fishbyte, 2, 12-19.

Pauly, D., Ingles, J., \& Neal, R. (1984). Application to shrimp stocks of objective methods for the estimation of growth, mortality and recruitmentrelated parameters from length-frequency date (ELEFAN I and II). Penaeid shrimps-Their biology and management. Fishing News Books Ltd. 308 p.
Pember, M. B., Newman, S. J., Hesp, S. A., Young, G. C., Skepper, C. L., Hall, N.G., \& Potter, I.C. (2005). Biological parameters for managing the fisheries for Blue and King Threadfin Salmons, Estuary Rock Cod, Malabar Grouper and Mangrove Jack in North Western Australia. Fisheries Research and Development Corporation (FRDC). Centre for Fish and Fisheries Research, Murdoch University. Australia. p.172.

Rengi, P., Tang, U.M., Syahza, A., \& Ikhwan, Y. (2015). Status, exploration potential and resource management of Kurau (Eleutheronema tetradactylum) fish in overfishing area (Case study in Bengkalis district, Riau Province). International Journal of Research in Earth \& Environmental Sciences, 3(2), 8-13.

Ridho, M. R., Rahardjo, M. F., \& Franata, A.Y. (2010). Feeding habits and length-weight relation of Senangin Fish (Eleutheronema tetradactylum Shaw) caught in Sungsang Waters, South Sumatera. Proceeding of an International SeminarWorkshop on Integrated Lowland Development and Management, 1-6.

Sparre, P., \& Venema, S.C. (1992). Introduction to Tropical Fish Stock Assessment. Rome: FAO Fisheries Technical Paper. No. 306, 470 p.

Uchiyama, J., \& Boggs. (2006). Length-weight relationships of dolphinfish, Coryphaena hippurus, and wahoo, Acanthocybium solandri: Seasonal effects of spawning and possible migration in the Central North Pacific. Marine Fisheries Review. 68(1-4), 19-29.

Zamidi, I., Samat, A., Zaidi, C. C., Mazlan, A. G., Alam, G. M., Al-Amin,A. Q., \& Simon, K. D. (2012). Fecundity and temporal reproductive cycle of Four Finger Threadfin (Eleutheronema tetradactylum) in Malaysian Coastal water. Asian J. Anim. Vet. Adv, 1-10. 